\title{
The Biological Value of the Proteins of Lucerne and Trefoil and of an Earthnut Meal, as Determined by the Thomas-Mitchell Method
}

\author{
BY R. H. ARMSTRONG AND B. THOMAS \\ Department of Agriculture, King's College, Newcastle upon Tyne
}

(Received 13 March 1950)

Grass undoubtedly constitutes the major source of protein for stock-feeding in this country, and it is a surprising fact that our knowledge of the quality of this protein is so limited as to be almost negligible. Crampton (1934) and Crampton \& Finlayson (1935), in the course of investigations into the nutritive value of young pasture grass and of certain pure species, in which they used the rabbit as their experimental animal, claimed to have obtained some indication of protein quality. The cow has been used by Morris, Wright \& Fowler (1936) in a study of the protein value of pasture grass for milk production at different periods of the growing season. Bartlett, Henry, Kon, Osborne, Thompson \& Tinsley (1938) successfully employed rats in determining, by the Thomas-Mitchell method (Mitchell, 1923-4), the biological value of the proteins in artificially dried and sun-cured pasture grass of high protein content. The same experimental procedure was used by Smuts (1938) in determining the biological value of lucerne protein for both rats and sheep. Turk, Morrison \& Maynard (1934) had previously applied the method to sheep fed lucerne hay. Chibnall (1939) and Lugg \& Weller (1 944, 1948a,b) have used amino-acid analysis on extracted grass proteins as a means to the study of quality. The method of Osborne, Mendel \& Ferry (19 I9), with the guinea-pig as experimental animal, has been used by Thomas \& Armstrong (1950) for the investigation of protein quality in swards and herbage species.

It may be said that most attempts to assess the quality of proteins have followed one of two lines of approach, namely $(a)$ a study of the nitrogen balance, and $(b)$ the measurement of body-weight increase under defined conditions. The first of these is exemplified by the method of Thomas and Mitchell, and the second by that of Osborne et al. (1919). In contrast to the latter procedure, which has been discussed at some length by Thomas \& Armstrong (1950), the Thomas-Mitchell method affords a direct means of assessing the adequacy of dietary protein for supplying the amino-acid requirements of the body, measuring both loss during digestion and the extent to which absorbed nitrogen is utilized within the body, i.e. the biological value of the protein.

The guinea-pig would appear to be the ideal experimental animal for biological value work on grass; it can exist on a diet comprised wholly of grass, whether fresh or dried, or of high or low protein content. It has so far been the experience of the authors, however, that the maintenance of guinea-pigs in thriving condition, and without loss of weight, on a diet low in nitrogen is so difficult as to be almost impossible. Of thirteen 
diets fed, twelve proved entirely unsatisfactory, the experimental animals without exception losing appetite and weight. The thirteenth diet, on first trial, gave fairly satisfactory results, which could not, however, be reproduced. It should be noted that Kik (1943) used guinea-pigs for the determination of biological value, by the Thomas-Mitchell method, of the proteins of individual herbage species. Many of his animals lost weight while on a diet low in nitrogen, and it might be maintained that the results are open to question on this score. Smuts (1935), in studying the relationship between basal nitrogen metabolism and energy metabolism, appears to have had some success in feeding a diet low in nitrogen to guinea-pigs, although it is not clear how many of his experimental animals had to be discarded because they lost weight.

The rat has been used extensively for the purpose of the Thomas-Mitchell method, and has, in fact, been employed by Bartlett et al. (r938) in work on pasture grass, and by Smuts (1938) on lucerne. The former workers fed only the youngest grass with crude protein contents of $23 \%$ or more, and pointed out that it was necessary to minimize bulk in order to allow for the ingestion of a sufficiency of digestible protein. The latter used lucerne which appears to have been of $17.6 \%$ crude protein content.

The present authors have had very little success in the feeding of grasses low in protein. When the crude protein is much less than $20 \%$, the limited capacity of the rat to ingest bulk, and the lower digestibility of the protein, militate against the animal's thriving, and a loss of weight is the usual result. It may be added that failure was experienced in an attempt to feed lucerne of $17.5 \%$ crude protein content.

The purpose of the work to be described here was to determine the biological value of two herbage species, namely lucerne and trefoil with the rat as experimental animal. The fact that both species are leguminous gave reasonable assurance that the crude protein content would be in the region of $20 \%$ provided that sampling was not deferred until a late stage of the growing period. The simultaneous determination of biological value in a sample of undecorticated earthnut meal provided a useful standard for comparison.

\section{EXPERIMENTAL}

Materials. Samples of lucerne (Medicago sativa) and trefoil ( $M$. lupulina) were obtained from pure stands of the species growing in the Nursery at the King's College farm of Cockle Park in Northumberland. They were cut on 14 May, when the trefoil was in early flower and the lucerne in the advanced leafy stage. Both samples were exposed to the air for 1 week, and drying was completed in an electric oven at a temperature not exceeding $50^{\circ}$. They were then ground in a Christy-Norris (Christy and Norris Ltd., Chelmsford) mill with a $\frac{1}{32}$ in. screen. The crude protein contents of the lucerne and trefoil were 23.0 and $20.6 \%$ respectively, and of the earthnut meal used as a control, $32 \cdot 8 \%$.

Diets. The dietary protein level normally adopted in the determination of biological value should be such as to provide a sufficiency of digestible protein for maintenance, with some excess to allow for growth. In the investigation to be described the diets contained 10 \% crude protein. A preliminary trial had shown that lucerne protein had a digestibility of between 55 and $60 \%$ and it was assumed (correctly, as will be shown 
later) that the digestibility of the trefoil protein was not markedly different; a higher level of protein intake would thus have been desirable. 'This, however, was impracticable in view of the fact that $48 \%$ of trefoil had to be included in the diet in order to provide even $10 \%$ of crude protein.

'The composition of the diets fed is given in Table $\mathbf{I}$.

\section{Table I. Percentage composition of diets}

$\quad$ Component
Lucerne
Trefoil
Earthnut meal
Dried egg (ether-extracted)
Glucose
Maize starch
Potato starch
Lard
Agar
Minerals

$\begin{array}{cc}\text { Low-nitrogen diets } \\ \text { A } \\ - & -- \\ - & - \\ \cdots & \cdots- \\ 5.5 & 5.5 \\ 20.5 & 20.5 \\ 40.0 & 34.0 \\ 14.0 & 10.0 \\ 15.0 & 15.0 \\ \cdots . & 10.0 \\ 5.0 & 5.0\end{array}$
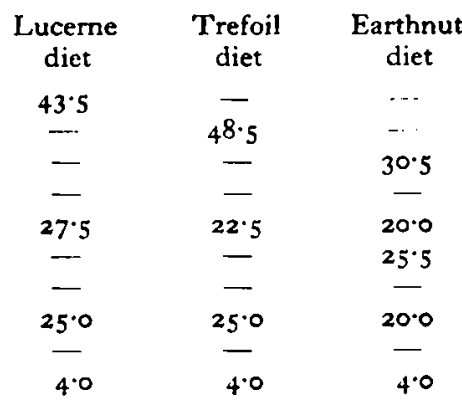

It will be noted that the composition of low-nitrogen diet $\mathrm{B}$, fed during the last period of the trial, differed from that of diet $\mathrm{A}$, which was used in the first period, in that it included to \% agar. This alteration was consequent on the experience gained in feeding diet $A$, which showed that the consistency of the faeces was somewhat unsatisfactory and their passage irregular, and was in accordance with the recommendations of Smuts \& Marais (1938) who normally included $2 \%$ agar in all lownitrogen diets fed to rats, but increased the level to $14 \%$ when the protein diets subsequently to be fed were of high fibre content. The egg protein used was prepared in accordance with the practice of Henry, Kon \& Watson (1937) and contained $69.2 \%$ crude protein. A mineral mixture was made up to the formula of Hubbell, Mendel \& Wakeman (I937), A.R. reagents being used. In compounding the diet that contained the earthnut meal, the lard content was reduced from 25 to $20 \%$ because of the difficulty experienced in obtaining a good 'mix' at the higher fat level. When a fresh batch of any diet was required, the fat was melted, added to the dry components and the whole thoroughly mixed before being passed through a $2 \mathrm{~mm}$. sieve. That portion of the diet not required for current use was stored in a refrigerator.

Management. The trial comprised five feeding periods, each of I I days. During the first 5 days of the period the experimental animal was allowed to adjust itself to the nitrogen intake, the nitrogen balance of the animal being determined in the remaining 6 days. All animals received the low-nitrogen diet during the first and fifth periods, the protein diets being fed in the interval.

Young rats which were with one exception of the albino type and all of average weight, 90-100 g., were used, no attempt being made to select litter-mates. Of twelve animals comprising six of each sex, put on to the low-nitrogen diet $\mathrm{A}$, two does lost appetite and weight and were replaced by males which received the low-nitrogen diet only during period 5. The rats were housed individually on circular mesh floors 
supported within cylindrical glass vessels of internal diameter $8 \frac{1}{2}$ in. and height 9 in. The cages were of a pattern similar to that used by Henry et al. (1937). A period of 2-3 days was allowed for the animals to become accustomed to their cages before the experiment was commenced.

Food was given once daily, and live weights were determined every other day while collection of faeces and urine was proceeding. Approximate food consumption was noted during the 5 days before collection, and it was thus possible to adjust food supply to the requirement of the individual animal before collection began. While the latter was proceeding, food residues were collected and stored in beakers, to be weighed and analysed later. Throughout the experiment the feed was weighed into clean jars and mixed with water, the proportion of the latter being adjusted according to the texture of the diet; admixture with water was necessary in order to minimize scattering. It was found that the lucerne and trefoil diets required about equal weights of water, and the earthnut meal and low-nitrogen diets one-third of their weights. With all diets the experimental animals received daily three drops of cod-liver oil and $0.5 \mathrm{ml}$. of a yeast extract (equivalent to $0.5 \mathrm{~g}$. dried yeast). The protein diets were fed as follows: in period 2 each of the three diets was fed to four rats; at the beginning of period 3 any group of four was divided into two pairs, each of which was allocated to one of the remaining two diets; during period 4 each pair received the third diet.

Collection of excreta. Each animal began the 6 days devoted to collection of excreta in a clean cage, the technique of collection being essentially the same as that of Henry et al. (1937). Where scattering of food had occurred to any considerable extent the filter pad, together with all residues, was removed to facilitate separation.

Analysis. During periods 2, 3 and 4 , the crude protein and moisture contents of each of the diets were determined daily, in order to allow calculation of the dry matter and nitrogen intakes of the animals. In the periods of low-nitrogen feeding ( $\mathrm{I}$ and 5 ), crude protein determinations were omitted. Food residues were collected from each animal in all periods, dried at $100^{\circ}$, and weighed. Determination of the nitrogen content of residues collected during periods of protein feeding was especially necessary when grass was fed; there was a tendency on the part of the animals to separate and reject the grass component, with the result that many of the food residues proved to have a crude protein content of more than $10 \%$. The nitrogen content of the total yield of faeces from any individual animal was determined by the Kjeldahl procedure. Where trefoil and lucerne diets were fed, a comparatively large bulk of faeces had to be dealt with, and up to $200 \mathrm{ml}$. of conc. sulphuric acid were required to effect complete digestion. Great care had to be taken in the early stages of digestion in order to control the serious frothing which invariably occurred. The digest was made to volume and the nitrogen content of portions determined. In the determination of urinary nitrogen, the collected bulk was adjusted to volume and duplicate $100 \mathrm{ml}$. portions were used for analysis.

\section{RESULTS}

The biological values found, together with the coefficients for true and apparent digestibility, and complete nitrogen-balance data are shown in Table 2.

Changes in the endogenous urinary and metabolic faecal nitrogen, as determined in 
Table 2. Nitrogen-balance data for rats given lucerne, trefoil or earthnut meal as a source of nitrogen

(Figures relating to nitrogen intake and excretion are daily means)

( $L=$ Lucernc; ' $T=$ trefoil; $E=$ earthnut)

$\begin{array}{cccc}\text { Mean Change } & \text { Mean } & & \text { Taily } \\ \text { weight in wt. } & \text { dry- } & \text { Total } & \text { Total digesti- } \\ \text { of during } & \text { matter Nitrogen faecal urinary bility of Bio- }\end{array}$

\begin{tabular}{|c|c|c|c|c|c|c|c|c|c|c|}
\hline Period & $\begin{array}{c}\text { Animal } \\
\text { no. }\end{array}$ & Diet & $\begin{array}{c}\text { animal } \\
\text { (g.) }\end{array}$ & $\begin{array}{l}\text { period } \\
\text { (g.) }\end{array}$ & $\begin{array}{c}\text { intake } \\
\text { (g.) }\end{array}$ & $\begin{array}{l}\text { intake } \\
\text { (mg.) }\end{array}$ & $\begin{array}{l}\text { nitrogen } \\
\text { (mg.) }\end{array}$ & $\begin{array}{l}\text { nitrogen } \\
\text { (mg.) }\end{array}$ & $\begin{array}{c}\text { nitrogen } \\
(\%)\end{array}$ & $\begin{array}{l}\text { logical } \\
\text { value }\end{array}$ \\
\hline \multirow[t]{10}{*}{ I } & I & Low-nitrogen & $94 \cdot 5$ & -+ & $8 \cdot 10$ & - & $29 \cdot 76$ & $23 \cdot 68$ & --. & $\ldots$ \\
\hline & 2 & & $97 \cdot 0$ & +1 & $8 \cdot 5^{8}$ & - & 25.90 & $24^{\circ} 5^{\circ}$ & 一 & - \\
\hline & 3 & & I I $9 \cdot 3$ & -3 & $7 \cdot 72$ & - & $23 \cdot 63$ & $21 \cdot 24$ & 一 & 一 \\
\hline & + & & $97 \cdot 3$ & -4 & $8 \cdot 10$ & - & $26 \cdot 84$ & $29 \cdot 39$ & 一 & - \\
\hline & 5 & & $102 \cdot 8$ & 0 & $8 \cdot 12$ & - & 25.67 & $22 \cdot 75$ & - & - \\
\hline & 6 & & $105 \cdot 8$ & -7 & $7 \cdot 58$ & - & $28 \cdot 29$ & $26 \cdot 61$ & 一 & - \\
\hline & 7 & & $107 \cdot 8$ & -7 & $7 \cdot 78$ & - & $22 \cdot 46$ & 24.51 & - & -- \\
\hline & 8 & & $96 \cdot 5$ & +1 & $8 \cdot 35$ & - & $21 \cdot 24$ & 23.89 & 一 & -- \\
\hline & 9 & & $91 \cdot 0$ & -3 & $7 \cdot 88$ & - & $22 \cdot 34$ & $22 \cdot 13$ & 一 & - \\
\hline & $10 *$ & & $91 \cdot 5$ & $-\mathrm{I}$ & $6 \cdot 63$ & 一 & $21 \cdot 29$ & $25 \cdot 20$ & 一 & - \\
\hline \multirow[t]{12}{*}{2} & $\mathbf{I}$ & L & $101 \cdot 8$ & +5 & $9 \cdot 70$ & $168 \cdot 83$ & 63.01 & $86 \cdot 86$ & 83.4 & $55^{\circ} 5$ \\
\hline & 2 & $\mathrm{~T}$ & 90.4 & -4 & $7 \cdot 3 \circ$ & 118.67 & $52 \cdot 49$ & $70 \cdot 88$ & $73 \cdot 6$ & $43 \cdot 8$ \\
\hline & 3 & $\mathrm{E}$ & $132 \cdot 2$ & +3 & $9 \cdot 42$ & 163.17 & 33.53 & $90 \cdot 13$ & $96 \cdot 8$ & $57 \cdot 5$ \\
\hline & 4 & $\mathbf{L}$ & 104.2 & +3 & $9 \cdot 85$ & I $71 \cdot 24$ & $42 \cdot 58$ & 94.50 & $92 \cdot 2$ & $58 \cdot 8$ \\
\hline & 5 & $T$ & $97 \cdot 2$ & -4 & $8 \cdot 16$ & 130.48 & $60 \cdot 66$ & $75 \cdot 69$ & $72 \cdot 7$ & $41 \cdot 0$ \\
\hline & 6 & $\mathrm{E}$ & I 3.4 & +3 & 9.08 & 159.17 & $4 I \cdot 4 I$ & $91 \cdot 00$ & $93 \cdot 8$ & $56 \cdot 7$ \\
\hline & 7 & I, & $109 \cdot 8$ & -2 & 10.89 & $187 \cdot 40$ & $82 \cdot 82$ & 85.69 & $72 \cdot 3$ & $54 \cdot I$ \\
\hline & 8 & $\mathbf{T}$ & 90.4 & -7 & $7 \cdot 69$ & $112 \cdot 31$ & $5 r \cdot 33$ & 59.50 & $73 \cdot 3$ & $52 \cdot 3$ \\
\hline & 9 & $\mathbf{E}$ & $99^{\circ} 8$ & +3 & $8 \cdot 59$ & I $48 \cdot 99$ & 37.91 & $8 I \cdot 09$ & $90 \cdot 8$ & $57 \cdot 5$ \\
\hline & 10 & I, & $97 \cdot 6$ & 0 & $8 \cdot 65$ & $149 \cdot 83$ & $50 \cdot 16$ & 70.91 & $83 \cdot 5$ & 62.7 \\
\hline & I I & $\mathrm{T}$ & 104.4 & -6 & $8 \cdot 12$ & 124.53 & $54 \cdot 83$ & $72 \cdot 92$ & $76 \cdot 7$ & $47 \cdot 8$ \\
\hline & 12 & $\mathrm{E}$ & $106 \cdot 0$ & +1 & $I x \cdot 24$ & 192.09 & $6 I \cdot 83$ & 85.03 & $84^{\cdot 6}$ & $63 \cdot 3$ \\
\hline \multirow[t]{12}{*}{3} & $\mathbf{I}$ & $\mathbf{T}$ & $98 \cdot 0$ & -1 & $6 \cdot 86$ & 115.47 & 47.02 & $69 \cdot 42$ & $80 \cdot 4$ & $48 \cdot 7$ \\
\hline & 2 & $\mathrm{~L}$ & $96 \cdot 8$ & +2 & $9 \cdot 3^{8}$ & I 58.82 & $57 \cdot 64$ & $88 \cdot 17$ & $80 \cdot 1$ & $48 \cdot 3$ \\
\hline & 3 & $\mathrm{~T}$ & 132.0 & 0 & $9 \cdot 90$ & $155^{\circ} 41$ & $58 \cdot 57$ & $92 \cdot 31$ & $8 \mathrm{I} \cdot 2$ & $44 \cdot 7$ \\
\hline & 4 & $\mathrm{~T}$ & 103.5 & 0 & $8 \cdot 44$ & 130.38 & $46 \cdot 79$ & $73 \cdot 76$ & $8 I \cdot I$ & $56 \cdot 0$ \\
\hline & 5 & I. & 102.8 & -1 & $9 \cdot 31$ & $154^{\circ} 69$ & 53.67 & $86 \cdot 36$ & $83 \cdot 2$ & $47 \cdot 6$ \\
\hline & 6 & $\mathrm{~L}$ & I I 9.0 & -2 & 9.50 & I 55.46 & $53 \cdot 32$ & 93.09 & 85.6 & $48 \cdot 9$ \\
\hline & 7 & E & $125^{\circ} 0$ & +10 & $I I \cdot I 4$ & 193.98 & $42 \cdot 24$ & $106 \cdot 37$ & 95.5 & $56 \cdot 2$ \\
\hline & 8 & $E$ & $98 \cdot 0$ & +6 & $6 \cdot 54$ & $97 \cdot 85$ & 23.10 & $5 I \cdot 92$ & $96 \cdot 5$ & 65.7 \\
\hline & 9 & $' \boldsymbol{\Gamma}$ & $99^{\circ} 0$ & -1 & $7 \cdot 43$ & 123.22 & 49.94 & $70 \cdot 33$ & 76.4 & $49 \cdot 2$ \\
\hline & 10 & $\mathbf{E}$ & $97 \cdot 6$ & +7 & $8 \cdot 65$ & $149 \cdot 83$ & $50 \cdot 16$ & 70.91 & 83.5 & $62 \cdot 7$ \\
\hline & II & $\mathrm{E}$ & $102 \cdot 3$ & +7 & $9 \cdot 63$ & $172 \cdot 73$ & 43.64 & $93 \cdot 93$ & $92 \cdot 6$ & $53 \cdot 9$ \\
\hline & 12 & $\mathbf{L}$ & III 0 & +4 & 12.59 & $216 \cdot 35$ & $73.77 t$ & $92 \cdot 73$ & $8 I \cdot 0$ & $61 \cdot 9$ \\
\hline \multirow[t]{12}{*}{4} & $\mathbf{I}$ & E & 99.0 & $+r 1$ & $8 \cdot 10$ & $142 \cdot 25$ & $29 \cdot 75$ & $82 \cdot 25$ & $99^{\circ} 0$ & $56 \cdot 3$ \\
\hline & 2 & $\mathrm{E}$ & $98 \cdot 0$ & +4 & $7 \cdot 88$ & 138.65 & 35.00 & $82 \cdot 29$ & $89 \cdot 9$ & $51 \cdot 3$ \\
\hline & 3 & $\mathrm{~L}$ & 140.4 & +2 & 10.47 & 180.07 & 60.08 & $95 \cdot 96$ & 83.0 & $51 \cdot 6$ \\
\hline & 4 & $\mathrm{E}$ & $107 \cdot 8$ & +3 & $7 \cdot 8 \mathrm{I}$ & 135.81 & $28 \cdot 5^{8}$ & $8 I \cdot I_{4}$ & $92 \cdot I$ & $56 \cdot 2$ \\
\hline & 5 & E & $104 \cdot 2$ & +3 & $8 \cdot 40$ & $148 \cdot 70$ & $33 \cdot 83$ & $92 \cdot 18$ & 93.5 & $46 \cdot 1$ \\
\hline & 6 & $\mathrm{~T}$ & 108.0 & 0 & 6.44 & $96 \cdot 31$ & $40 \cdot 24$ & $63 \cdot 14$ & $75 \cdot 6$ & $4 x \cdot 7$ \\
\hline & 7 & $\mathrm{~T}$ & 116.2 & -4 & $8 \cdot 19$ & 131.96 & $6 x \cdot 83$ & 80.59 & $71 \cdot 3$ & $36 \cdot 4$ \\
\hline & 8 & $\mathrm{~L}$ & $101 \cdot 8$ & +8 & $8 \cdot 21$ & $142 \cdot 84$ & $45 \cdot 49$ & $69 \cdot 13$ & 86.8 & $58 \cdot 7$ \\
\hline & 9 & I. & $106 \cdot 2$ & +2 & $9 \cdot 77$ & 166.98 & $48 \cdot 99$ & $84 \cdot 45$ & $86 \cdot 9$ & $57 \cdot 9$ \\
\hline & 10 & $\mathrm{~T}$ & 100.2 & +2 & $6 \cdot 27$ & 104.79 & $40 \cdot 83$ & $62 \cdot 57$ & $75 \cdot 7$ & $45 \cdot 8$ \\
\hline & II & $\mathrm{L}$ & 120.8 & +7 & 9.54 & $165 \cdot 12$ & $58 \cdot 33$ & $85 \cdot 32$ & $83 \cdot 5$ & $53 \cdot 3$ \\
\hline & 12 & $\mathrm{~T}$ & $109 \cdot 8$ & +4 & 9.63 & $161 \cdot 17$ & 68.82 & 100.43 & $7 \mathrm{I} \cdot 1$ & $34 \cdot 3$ \\
\hline
\end{tabular}

- See text, p. I71, about animals nos. I I and 12 .

+ Calculated from nitrogen intake of animal no. 12 using mean apparent digestibility coefficient for all other animals on this diet. Faecal sample lost as result of an accident. 
Table 2 (cont.)

5

$\begin{array}{cc}\text { Low-nitrogen } & 109^{\circ} 0 \\ 106.0 \\ 136.0 \\ 116.0 \\ 114^{\circ} \\ 117^{\circ} \\ 127^{\circ} \\ 101^{\circ} \\ 100 \\ 108^{\circ} \circ \\ 124^{\circ} \\ 115^{\circ}\end{array}$

$\begin{array}{rrr}-1 & 7.21 & - \\ -4 & 6.88 & - \\ -3 & 7.81 & - \\ +3 & 10.39 & - \\ +2 & 8.06 & - \\ +3 & 8.31 & - \\ +7 & 11.32 & - \\ -2 & 6.46 & - \\ -3 & 7.10 & - \\ +4 & 7.59 & - \\ -1 & 7.79 & - \\ +3 & 11.74 & -\end{array}$

24.74
$\times 7.50$
$22 \cdot 40$
$20 \cdot 07$
$22 \cdot 40$
$23 \cdot 22$
$29 \cdot 87$
$22 \cdot 40$
19.49
16.69
25.55
23.80

$21 \cdot 23$
$22 \cdot 14$
$22 \cdot 40$
$26 \cdot 08$
$16 \cdot 77$
$20 \cdot 05$
$22 \cdot 31$
$15 \cdot 31$
$21 \cdot 26$
$18 \cdot 16$
$18 \cdot 48$
$25 \cdot 78$

periods $I$ and 5 , were assumed to follow a linear course, and intermediate values were calculated for periods 2-4 of test-protein feeding. With animals nos. I 1 and 12, it was assumed that the excretion of faecal and urinary nitrogen in period I would have been equal to the mean for the ten animals for which values were actually obtained.

The amount of bulk in the three protein-containing diets was certainly greater than in the low-nitrogen diet fed in period $\mathrm{x}$. Whether the addition of agar during period 5 made the diet comparable with those fed during periods $2-4$ is extremely doubtful, since it should be noted that in only one instance in period 5 did the metabolic faecal nitrogen excreted per g. dry matter ingested exceed that excreted in period I. As it is established that bulk is directly related to the excretion of metabolic faecal nitrogen (Mitchell 1923-4), it should be admitted that some error is inevitable in the absence of any measure designed to equalize the bulk of all the diets fed. No such equalization has been attempted in this work. The output of endogenous urinary nitrogen was, in all instances, less in period 5 than in period $\mathrm{r}$.

The experimental animals did not respond well to the low-nitrogen diet during period I, eight of them losing weight over the last 6 days. During period 5, results were rather more satisfactory, only six animals losing weight. The diet containing earthnut meal produced body-weight increases on all occasions, whereas on lucerne and trefoil eight and five animals respectively gained in weight. A major factor in the poor results obtained from the trefoil was the bulky nature of the feed; there was much scattering, and food intake was reduced.

The mean biological values and apparent and true digestibility coefficients of the proteins contained in the three feeding-stuffs studied are shown in Table 3.

Table 3. Mean values with their standard errors for biological values and true and apparent digestibility coefficients of the nitrogen of lucerne, trefoil and earthnut meal determined on groups of twelve rats

Biological value

Apparent digestibility coefficient

True digestibility coefficient

$\begin{array}{rc}\text { Lucerne } & \text { Trefoil } \\ 54 \cdot 9 \pm 1 \cdot 50 & 45 \cdot 1 \pm \mathrm{I} \cdot 8 \mathrm{I} \\ 65 \cdot 9 \pm \mathrm{I} \cdot 33 & 57 \cdot 9 \pm \mathrm{I} \cdot 0 \mathrm{I} \\ 83.5 \pm 1 \cdot 37 & 75 \cdot 8 \pm 1 \cdot 05\end{array}$

Statistical examination, which followed the paired $t$ technique of 'Student' (1925), showed that the biological values of the proteins of both lucerne and earthnut meal were 
significantly higher than that of the trefoil. No significance could be attached to the difference between the first two. It is noteworthy that animals nos. 2 and 5 gave relatively low biological values on all diets, whereas animal no. 8 always gave values higher than the mean for all remaining animals. The very low biological value obtained for trefoil with animal no. 12 is difficult to account for in view of the fact that it gained more weight than any of the rest receiving the diet, and when on the other two proteincontaining diets gave biological values above average.

Both the apparent and true digestibility coefficients of the earthnut-meal protein were considerably greater than those for either lucerne or trefoil. Of these last, the lucerne protein was digested to an appreciably greater extent than that of the trefoil.

\section{DISCUSSION}

It is significant that neither Bartlett et al. (1938) nor Smuts (1938) used the 'ThomasMitchell procedure for determining the biological values of grasses of low or even medium protein content. Indeed the former workers have voiced the opinion that the limited digestive capacity of the rat will not allow of any but the youngest grass being fed. This view is borne out by certain of the results obtained in this experiment; only five out of twelve rats gained weight on the diet containing trefoil, even though this had a crude protein content ( $20.6 \%$ of dry matter) that would usually be regarded as high. An examination of the mean dry-matter intakes (Table 2) shows that, without exception, any one rat consumed less dry matter on the diet containing trefoil than when on the other two protein diets. The primary reason for rats failing to thrive on diets containing herbage of low or medium protein content is undoubtedly their inability to handle the bulk characteristic of such materials and, consequently, their failure to ingest a sufficiency of protein. It would appear that, for the purpose of this work, a plant such as trefoil, though containing over $20 \%$ of crude protein, must be regarded as of no more than medium protein content. It thus seems that the Thomas-Mitchell method, as used with rats, can only be satisfactorily applied to herbage of the highest protein content. As it is certain that many swards and species never attain the requisite protein content, even when cut in the earliest stages of growth, the method is obviously of severely limited usefulness in the field of grassland research. The feeding of a protein extractive such as that obtained by the procedure of Lugg \& Weller (1944) may be a possible solution of this difficulty.

As already indicated, work so far carried out in this laboratory has shown that it is impracticable to use the guinea-pig for the determination of biological values of proteins, but it is conceivable that there are other small experimental animals for which a satisfactory low-nitrogen diet could be provided, and which could handle the relatively large bulk supplied by diets containing high proportions of grassland herbage.

It will have been noted (Table 3 ) that there were comparatively large differences in the digestibility of the proteins of the three feeds under trial. The customary procedure in such tests is to equalize dietary protein levels on the basis of total content of crude protein, without regard to digestibility. This adjustment would, in the opinion of the authors, be better based on the content of digestible crude protein. Admittedly, when foods of the same class are under trial, differences in digestibility of protein are 
unlikely to be considerable. Where such differences exist, and where differences in bulk do not affect consumption of dry matter, some error is likely to arise by reason of the greater proportion of ingested nitrogen which will be used for maintenance with foods of lower digestibility. A higher biological value is attributed to nitrogen so used.

It will be seen that the biological values found in this work do not indicate that any one of the three feeds under trial contains protein of particularly high quality. The low value obtained for trefoil is the more noteworthy, in that the lower digestibility of the protein and the greater bulk would give this food a favourable bias.

Smuts \& Malan (1938) have applied the Thomas-Mitchell procedure to the determination of the biological value for rats of a series of plant proteins, which included those of lucerne and earthnut. They obtained a mean biological value of $72 \cdot 0 \pm 1 \cdot 19$ for earthnut protein fed at a level of $8.5 \%$, and values of $60.0 \pm \mathrm{r} \cdot 09$ and $6 \mathrm{I} \cdot 0 \pm 4.63$ for lucerne fed at levels of 9.7 and $6.9 \%$ respectively. This highly significant difference between these two proteins was not confirmed by the results of the present work. It should be added, however, that Smuts (1938) investigated the growth-promoting properties of the two proteins, using a paired-feeding technique, and obtained results which showed earthnut protein to be superior to that of lucerne. On the other hand, Mitchell, Burroughs \& Beadles (1936) found for earthnut protein a biological value for rats very close to that obtained in this investigation.

Neither Smuts \& Malan (1938) nor Mitchell et al. (1936) define clearly the exact source of the earthnut protein fed; the former describe it merely as a peanut meal and do not state the crude protein content which, however, may be calculated as $56.7 \%$. The apparent and true digestibility coefficients are given as 74.8 and $89.9 \%$ respectively, and are in close agreement with those for the protein of the earthnut meal fed by the present authors. 'The source of this protein used by Mitchell et al. appears to have been very similar to that of Smuts \& Malan. Though the latter fed their earthnut protein in a form markedly different from that used in the work here described, the results of Mitchell $e t a l$. lend no support to the view that such a difference would affect the biological value. Though the lower level at which Smuts \& Malan fed their protein might account in part for the greater biological value found, it would appear in the highest degree improbable that this factor has been wholly responsible. Moreover the results of Mitchell et al., who also fed earthnut protein at less than $10 \%$ of the diet, suggest that any such effect must have been very small.

It will be noted that Smuts \& Malan obtained a higher biological value also for lucerne. The material they fed appears to have had a crude protein content of $17.6 \%$ with apparent and true digestibility coefficients of 56.5 and 74.5 , as against values of $23 \cdot 0,65 \cdot 9$ and 83.5 respectively for the lucerne used in the present work. It is therefore probable that the lucerne was appreciably more mature.

It was to be expected that a seed protein such as that of earthnut would differ markedly in biological value from the proteins of herbage plants, and such a difference is, in fact, evident when earthnut and trefoil are compared. The difference between lucerne and trefoil, which can only be related to the amino-acid make-up of the two proteins, is more noteworthy in view of the findings of Chibnall (1939) and Lugg \& Weller (1944, 
I $948 a, b)$. These workers have so far been unable to provide evidence that herbage species differ to any appreciable extent in the make-up of their proteins, although it should be observed that they investigated only the leaf, and not the plant as a whole.

\section{SUMMARY}

I. The biological values of the proteins of lucerne and trefoil, at the late preflowering and early flowering stages respectively, and of an undecorticated earthnut meal were determined for rats by the Thomas-Mitchell method.

2. At a dietary protein level of $10 \%$ the mean biological value of the protein of lucerne was $54.9 \%$, of trefoil $45.1 \%$ and of earthnut meal $56.5 \%$ and the true digestibility $83.5,75.8$ and $93.0 \%$ respectively.

3. These values are compared with results obtained by other workers, and an attempt is made to account for the differences observed.

4. The limitations of the rat for measurement of the biological value of the proteins of grassland herbage were demonstrated, and the possibility of using other small experimental animals is discussed.

\section{REFERENCES}

Bartlett, S., Henry, K. M., Kon, S. K., Osborne, L. W., Thompson, S. Y. \& Tinsley, J. (1938). Biochem. Y. 32, 2024.

Chibnall, A. C. (1939), Protein Metabolism in the Plant. New Haven: Yale University Press.

Crampton, E. W. (1934). Emp. Y. exp. Agric. 2, 337.

Crampton, E. W. \& Finlayson, D. A. (1935). Emp. F. exp. Agric. 3, 33 I.

Henry, K. M., Kon, S. K. \& Watson, M. B. (1937). In Milk and Nutrition, Part 1, p. 37. Reading: National Institute for Research in Dairying.

Hubbell, R. B., Mendel, L. B. \& Wakeman, A. J. (1937). F. Nutrit. 14, 273.

Kik, M. C. (1943). Bull. Ark. agric. Exp. Sta. no. 434.

Lugg, J. W. H. \& Weller, R. A. (1944). Biochem. F. 38, 408.

Lugg, J. W. H. \& Weller, R. A. (1948a). Biochem. F. 42, 408.

Lugg, J. W. H. \& Weller, R. A. (1948b). Biochem. F. 42, 412.

Mitchell, H. H. (1923-4). F. biol. Chem. 58, 873 .

Mitchell, H. H., Burroughs, W. \& Beadles, J. R. (1936). F. Nutrit. 11, 257.

Morris, S., Wright, N. C. \& Fowler, A. B. (1936). $\mathcal{F}$. Dairy Res. 7. 97.

Osborne, T. B., Mendel, L. B. \& Ferry, E. L. (I919). F. biol. Chem. 37, 223.

Smuts, D. B. (1935). F. Nutrit. 9, 403.

Smuts, D. B. (1938). Onderstepoort F. vet. Sci. 10, 193.

Smuts, D. B. \& Malan, A. I. (1938). Onderstepoort F. vet. Sci. ro, 207.

Smuts, D. B. \& Marais, J. S. C. (1938). Onderstepoort f. vet. Sci. II, 15 I.

'Student' (1925). Metron, 5, I05.

Thomas, B. \& Armstrong, R. H. (1950). Emp. F. exp. Agric. (In the Press.)

Turk, K. L., Morrison, F. B. \& Maynard, L. A. (1934). F. agric. Res. 48, 555. 